\title{
HARMONIZATION AND STANDARDIZATION OF THE ACCOUNTING AND ITS FUNCTIONS
}

\author{
PhD Elżbieta Wystocka, ,Czestochowa” University of Technology, \\ e-mail:wyslocka@zim.pcz.pl
}

\begin{abstract}
The process of harmonization and standardization of the accounting, which has been observed hitherto, is described in this paper. Particular attention has been given to changes that have been done in the Polish balance law and conditions which accompanied them. Special attention has been also paid to the implications which may be caused by the drawing up the financial statements according to International Financial Reporting Standards. Changes in the accounting have resulted in the fact that its main function which it fulfils is the information function. Detailed functions that arise from the main one have been also described in this paper.
\end{abstract}

Keywords: accounting, harmonization, standardization, function

JEL Codes: $M 41$

\section{Introduction}

Accounting has never worked and does not work currently as an independent system. It is rather a fragment of entire information system of business organization. It has developed in response to expectations and requirements of business, banking industry and also production practice. The development of tasks and respective functions performed by accounting is continually inspired by needs of practice.

It is beyond any doubts that accounting plays an extremely important role in market economy, especially in face of globalization of capital markets, where increasing need for comparable, transparent financial statements of companies is often noticeable. It had led to a decision of the European Union concerning adoption of International Accounting Standards (IAS) by all listed companies in the EU starting from January 1, 2005. Similarly Poland, which joined the European Union on May 1, 2004 was obliged to implement a variety of legal rules which are applicable in EU community.

\section{Harmonization and standardization of accounting}

The International Congress of Accountants in 1904 in St. Louis in the United States was the event, which is generally accepted as a beginning of initiatives directed to harmonization of accounting rules. After that Congress, the working group has been appointed. This group was obliged to perform international comparison research for accounting rules and principles in particular countries in order to prepare recommendation for reduce these differences ${ }^{1}$.

Endeavors to harmonize have materialized in 1973, when the International Accounting Standards Committee, (IASC) have been established. This organization was transformed into International Accounting Standards Board (IASB) in 2001, which took responsibility and exclusive rights to create international standards. New constitution has introduced new name for elaborated standards - until 2001 there were International Accounting Standards, whereas since 2001 all new standards have been called International Financial Reporting Standards. In the light of a new constitution, IASB is responsible for elaboration in accordance with the public interest of a set of

\footnotetext{
${ }^{1}$ A. Jaruga, Harmonizacja i standaryzacja, [in:] Międzynarodowe regulacje rachunkowości. Wpływ na rozwiazania krajowe, A. Jaruga (edit.), C.H. Beck, Warsaw 2002, p. 11.
} 
high quality, understandable and possible to enforce global accounting standards. Other aims include promotion of application and rigorous compliance with the standards and also activities towards unification of local accounting standards and International Financial Reporting Standards in order to make them congruent and based on high quality solutions. Thanks to the Regulation (EC) No 1606/2002 of the European Parliament and of the Council of 19 July 2002 implemented in the European Union, international accounting standards have been validated. This regulation has obliged member states to implement not later than on January 1, 2005 IFRS accepted by the European Commission as a basis for consolidated financial statements of companies listed on the regulated capital markets of the European Economic Area $(E E A)$. Works concerning convergence of IFRS with American United States Generally Accepted Accounting Principles (US GAAP) are also advanced. This cooperation even if full congruence is difficult to reach, may bring closer regulations included in these standards in order to prevent misunderstanding of financial statements. Introduction of IAS has required enormous changes in national financial systems in all member states in the European Union. Most of all, the tax, and administrative regulations have been influenced. These changes were associated often with vagueness and lack of full understanding of wording of international regulations. Additional problem for Central European countries was a relatively short period of companies' activity in the environment of the market economy.

In 1989, the age of socialist regime in Poland and central planned economy were over, and the period of political and economic transformation has begun. The process of replacement of universal information system with new system adjusted to requirements of global world has started. Stages of this transformation in Poland were materialized in the form of subsequently issued legal acts.

The first was the Regulation of the Ministry of Finance of 15 January 1991 on accounting rules. It was extremely important for development of Polish accounting system, because for the first time, the superior principles such as historical cost, accrual basis assumption, prudent valuation, commensuracy principle and basic rules for assets and liabilities valuation were presented. What is more, the regulation contained models of main elements of financial statements. ${ }^{2}$

Implementation of Accounting Act of 29 September 1994 enabled Polish solutions in the area of accounting to become closer to International Accounting Standards and Directives of the European Union. Additionally, balance sheet regulations have been separated from tax law, whereas the aim of accounting system was specified and defined as presentation of clear and reliable picture of business entity.

Understanding of motives of transformation of Polish accounting requires a thorough analysis of its political, economic, and sociological context. The socialistic system and isolation of Poland from the Western Europe influenced to a large extent the shape of local accounting standards. In a centrally planned economy, the accounting system constituted a form of control of government and a source of statistical information necessary for planning of future goals of the state. Companies were placed in political functions, which were more important than economic aims. $^{3}$ In majority of cases, prices were artificially set, and accounting system was rather responsible for safety of company's assets and reporting input data associated with costs. ${ }^{4}$ Competitive economy operated beside nationalized industry, which did not aim at transformation, but wanted to maintain a centrally protected position. Changes in perception of accounting came only during continuation of privatization process in the following years. ${ }^{5}$

\footnotetext{
${ }^{2}$ E. Pogodzinska-Mizdrak, Rachunkowość w historycznej perspektywie, [in:] Podstawy rachunkowości. Aspekty teoretyczne i praktyczne, B. Micherda (edit.), Wydawnictwo Naukowe PWN, Warsaw 2005, p. 53.

${ }^{3}$ K. Obloj, M. Kostera, Polish privatisation, action, symbolism and cultural barriers. Industrial and Environmental Crisis Quarterly, (1993), 7(3), pp. 7-21.

4 A. Jaruga, E. Walinska, A. Bankiewicz, The relationship between accounting and taxation in Poland, European Accounting Review, (1996) 5, pp. 883-897.

${ }^{5}$ I. Vellam, Implementation of International Accounting Standards in Poland: Can True Convergence be Achieved in Practice?, Accounting in Europe, Vol. 1, 2004, pp. 144-167.
} 
Accounting Act of 29 September 1994 was amended up to this date many times. Last relevant amendment was in 2000, and came into force in 2002. Amendments enabled to fulfill gaps, precise definitions and valuation rules and made the regulations congruent and compliant with IAS resolutions, EU directives and changing Polish legislation. Amendment of 18 March 2008 implemented by the act on changes in accounting act (Journal of Laws of the Republic of Poland, no 63, pos. 393) contained implementation of resolutions of Directive 2006/46/EC of the European Parliament and of the Council of 14 June 2006 amending Council Directives 78/660/EEC on the annual accounts of certain types of companies, 83/349/EEC on consolidated accounts, 86/635/EEC on the annual accounts and consolidated accounts of banks and other financial institutions and 91/674/EEC on the annual accounts and consolidated accounts of insurance undertakings (Text with EEA relevance) (OJ L 224, 16.08.2006, p. 1 - 7).

Implementation since 1 January 2006 of the obligation to prepare consolidated financial statements in accordance with IFRS by all companies and banks listed on stock exchanges in the European Union countries has been a good solution for the market. However, it should be underlined that this obligation does not concern all entities and during studies on statements, reader should be aware what entity is being presented and what kind of statements are used. Many Polish companies decided in 2002 to take advantage of certain solutions proposed by the international standards, because it was possible on the basis of amended accounting act. Nevertheless, it should be highlighted that introduction of international standards is relatively expensive and imposing an obligation of using IFRS on all companies simultaneously would be an unnecessary financial burden for the economy. At the same time as on harmonization of accounting, policymakers work on standardization of prospectuses in order to make the status of securities admitted to trade on the European stock exchanges equal. It requires to use a universal language of reporting, which would be clear for all potential users. Unification of prospectuses of companies applying for listing on the European exchanges may facilitate fund raising abroad, and at the same time contribute to capital inflow to the Warsaw stock exchange. Additionally, issuers will have the right to choose practically every stock exchange in Europe for their securities.

Implementation of obligation to prepare statements on the basis of IFRS facilitated the evaluation of listed companies performed by the research analysts. The reason for that is associated with the fact that international accounting standards to a large extent base on estimated values presented in the balance sheet and the profit and loss account. Subsidiaries, which did not decide to implement statements in accordance with standards, are often force to prepare reporting using three methods - for national, tax and consolidation purposes.

Accounting has been established as a group of practical methods of description of economy reality of micro companies. Popularization of application of this method results from the fact, that in management of business entities, a rationally chosen method of measurement and record of economic events and identification of associations between reasons and effects is indispensable. T. Kiziukiewicz claims that the problem of accounting functions should not be considered statically: "Similarly as the scope of accounting changes together with economic transformations, the function of the system converts. Is concerns especially changes in the hierarchy. Depending on the needs, also new functions may be identified". At the beginning, these changes resulted directly from experience of practitioners, however with the passage of time, the basis was found in particular theoretical concepts. Current recording solutions of accounting are a matter of modeling. ${ }^{7}$ Simultaneously with changes in Polish economy and enforced improvement of national accounting regulations, also functions performed by accountancy in business entities have changed.

\footnotetext{
${ }^{6}$ T. Kiziukiewicz, Problemy dostosowania rachunkowości do informacyjnych wymagań zarzadzania, Prace Naukowe Politechniki Szczecińskiej no 261, Szczecin 1984, p. 62.

7 Compare M. Gmytrasiewicz, Teoretyczne podstawy modeli ewidencji księgowej, SGPiS, Warsaw 1977, p. 5., Z. Głodek, Modelowanie i metody symulacyjne w rachunkowości, PWE, Warsaw 1988.
} 


\section{Accounting functions}

Accounting in business entities has to play many diversified roles which come out from its mission described as a holistic information system. A superior aim of accounting is to elaborate the information associated with the business activity. Because of that, the information function is a basic function of accounting. It depends on creating the information connected with business processes and adjustment to information needs of users in order to appropriately formulate opinions and make proper decisions.

Modern accounting system is oriented both on internal (from an enterprise) information users, and on external users from enterprise environment. Taking into account this classification of recipients who obtain information from accounting system, internal and external accounting information function can be distinguished.

The performance of internal informative function is observable in provision of economic and financial information which are prepared periodically in order to properly manage the enterprise with consideration of various hierarchy and organisational levels. These information are passed on to managers in the form of financial statements and periodical reports. Accounting, through fulfilment of internal informative function, allows users and the system itself to run information services for all management functions: planning, organising, coordinating motivating and control.

On the other hand, accounting through the external informative function, should provide information for appropriate entities from enterprise environment, especially for shareholders, co-owners, and other investors, banks (creditors), contracting parties, local societies, and government agencies (ministries, statistical offices etc.). Much information generated by accounting that are useful for external users in assessment of company's financial situation, are included in financial statements.

Informative function of accounting, which is appropriately realised, should enable to perform the following detailed functions:

- reporting, which concerns the final product of data processing in accounting system, that is preparation of reports, financial statements and statistical statements, adjusted to needs of internal and external recipients. Information are presented both in statements which show the general overview of entity's activity (for instance balance sheet, profit and loss account), and in reports or statements related with particular problems. Those reports and statements are basic carriers of information provided by accounting system.

- evidential, which is expressed in book-keeping and recording the appliances and devices in a way which enables to present in any case all documents, accountancy books and financial statements on the court, crime squads, or offices of inland revenue demand, as reliable evidence in legal and tax proceedings. Thanks to the obligation to keep the accounting documents, a possibility to find the evidence of every business action in enterprise occur.

- optimizing, which is characterised as a need for creation of foundation for choosing optimal activity scenario by providing the information which describe various decisive situations in business entities. In optimizing issues, such categories as: costs, revenues and financial results are often a choice criterion and a parameter of decision-making model. Sometimes, these categories refer to determining the most profitable relation between expenditures and results.

- control, which is most visible in provision of information about costs, revenues and results for various management levels regarded as responsible centres, in order to assess the progress in obtaining scheduled tasks and the level of exploitation of funds dedicated for these tasks, and also for control over produced costs. On the basis of provided information, some conclusions associated with future activities are formulated. Control function of accounting can be realised in the form of three kinds of control:

a) initial control, performed before the business activity really starts, and before any costs, revenues or profits are noticed 
b) current control, performed during the process of bearing costs, obtaining revenues and calculating profits, i.e. during the performance of business activities.

c) final control, performed after all activities have been completed in order to check all documents and assess revenues, costs and profits.

- analytical - associated with investigation and interpretation of information obtained from accounting in various sectional views in order to assess the financial standing, financial results and efficiency of business entity activities, and in order to determine the relations, reasons and outcomes of these elements.

Fulfilling by accounting such diversified functions is possible only when accounting system is well organised, and it created the possibilities of generating cross-sectional reporting information which are adjusted to specific and particular needs of process of enterprise management.

\section{Conclusions}

This framework presents the progress of harmonization of regulations concerning accounting, especially in Poland and describes functions performed by the accounting in market economy.

Applicable Accounting Act has brought Polish regulations significantly closer to international standards, especially after amendment in 2000. In addition, other amendments of the act are directed to harmonize with IFRS. A relevant obstacle on this way is a high level of severity of Polish tax law. The issue of training of accountants in the area of a proper use of International Financial Reporting Standards, which have a form of extensive guidebook requiring sophisticated skills, is also extremely important. Popularization of advantageous practices is also driven by investors' expectations. They are the most important users of financial statements, and require clear and high quality information relevant for decision-making process. Polish managers must understand that they prepare financial statements not because they are obliged to do it, but because they must provide necessary information for all users. It results from the basic function performed by accountancy in a modern company.

Generally, accounting is not only a matter for accountants, but also, or even above all, for managers and directors. Nevertheless, it became nowadays more visible. Accountants must question decision makers in the company all the time in order to receive an answer, because many transactions will not be included in the books, and subsequently in statements without their explicit response. This situation is caused by the construction of international standards, which contain many judgment elements. Classification of particular transaction depends largely on the intentions and plans of people who design a deal. During purchase of assets, the aim and purpose are important, e.g. for sale or long-term holding. The same transaction may be treated very differently depending on the plans and decisions of managers. They may be aware, how their decision is measured and included in the financial statement. As a result, management board must set up a farreaching cooperation with accountants.

There is a view, that a unified accounting system is impossible to develop, because rules and principles of accounting in particular country are design in a determined environment characterized by a specific economic, social, legal and educational system shaped during a long periods of historical development, geopolitical arrangements, and cultural heritage. A way for unification of rules and principles of "business language" is to identify factors, which cause differences between accounting systems and take efforts to standardize. The situation in which all business entities in all over a world prepare their financial statements in accordance with unified rules is desirable. Then, all signals flowing from global markets will be more accurately interpreted.

\section{References}

1. Głodek Z. - Modelowanie i metody symulacyjne w rachunkowości, PWE, Warsaw 1988.

2. Gmytrasiewicz M. - Teoretyczne podstawy modeli ewidencji księgowej, SGPiS, Warsaw 1977. 
3. Jaruga A. - Harmonizacja i standaryzacja, [in:] Międzynarodowe regulacje rachunkowości. Wptyw na rozwiqzania krajowe, A. Jaruga (edit.), C.H. Beck, Warsaw 2002.

4. Jaruga A., Walinska E., Bankiewicz A. - The relationship between accounting and taxation in Poland, European Accounting Review, (1996) 5.

5. Kiziukiewicz T. - Problemy dostosowania rachunkowości do informacyjnych wymagań zarzadzania, Prace Naukowe Politechniki Szczecińskiej no 261, Szczecin 1984.

6. Obloj K., Kostera M. - Polish privatisation, action, symbolism and cultural barriers. Industrial and Environmental Crisis Quarterly, (1993), 7(3).

7. Pogodzinska-Mizdrak E. - Rachunkowość w historycznej perspektywie, [in:] Podstawy rachunkowości. Aspekty teoretyczne i praktyczne, B. Micherda (edit.), Wydawnictwo Naukowe PWN, Warsaw 2005.

8. Vellam I. - Implementation of International Accounting Standards in Poland: Can True Convergence be Achieved in Practice?, Accounting in Europe, Vol. 1, 2004. 